\title{
Language, Culture, Idioms, and Their Relationship with the Foreign Language
}

\author{
Oktay Yağiz \\ Department of English Teaching, Faculty of Education, Atatürk University, Erzurum, 25240, Turkey \\ Siros Izadpanah \\ English Language Department, Islamic Azad University, Zanjan Branch, Iran
}

\begin{abstract}
This study explores the close relationship between language and culture. Nowadays, the issue of human communication is one of the most important subjects occupying the minds of linguists, anthropologists, psychologists, and philosophers. .Since it is the most important means for communication among human beings, the relation between language, culture, and their mutual interactions have high significance. The inextricable connection highlights various manifestations of conventionalized language including the idiomatic expressions as one of the important and pervasive language uses reflecting culture in real life. Like other types of figurative language, idioms appear to be the natural decoders of customs, cultural beliefs, social conventions, and norms. Idioms, as a major component of native-like communication, enable a language learner to understand the thoughts, emotions and views of the speakers of target language. For this reason, learning idioms provides learners with a significant chance to acquire information about the underlying parameters of a language. Awareness of figurative language particularly idioms will improve teaching and assist learners to have better communication strategies. Otherwise, accurate and appropriate target language use and understanding will be at risk and the learners will tend to transfer their native language conceptual structure which will most probably be inappropriate. The strong relationship among the language, culture, and the figurative branch of the language especially idioms need particular attention in language learning since it appears to have inadequate research. Therefore, a systematic knowledge of language and culture integration inside and beyond the classroom setting can be built up.
\end{abstract}

Index Terms — communication, culture, idioms, learning foreign language

\section{BACKGROUND}

Given that language is used to construct our social lives and using this understanding to improve our world, language and culture are inextricably intermingled. This togetherness has been widely highlighted in several linguistic, social and cultural studies (e.g. Alptekin, 2002; Brown, 1994; Bygate, 2005; Jiang, 2000; MacKenzie, 2012; Risager, 2007;). Peterson and Coltrane (2003) emphasize that to achieve desired communication, culturally appropriate language use appear to be a must. In other words, knowledge of linguistic features is not adequate for successful intercultural communication (Scarino, 2010). This knowledge, in fact, must be supported by an awareness of sociocultural context, tendencies, conventions, and norms in which the communication takes place (Baker, 2012). Likewise, Byram and Risager" s (1999, cited in Al-Issa, 2005) argument that culture has a crucial role in encoding and decoding messages corroborates with the above mentioned idea that culture is at the heart of communication. Culture as a body of knowledge of common beliefs, behaviors and values appear to be the factor to establish and interpret meaning in both verbal and nonverbal language. Alptekin explains (2002) this conceptualizing process as the enculturation of the foreign language learner and states: "Learners are not only expected to acquire accurate forms of the target language, but also to learn how to use these forms in given social situations in the target language setting to convey appropriate, coherent and strategically- effective meanings for the native speaker'. Thus learning a new language becomes a kind of enculturation, where one acquires new cultural frames of reference and a new world view, reflecting those of the target language culture and its speakers." (2002, p.58) The close relation between language, culture, and the integration of culture into language learning are not new phenomena (Cortazzi\& Jin, 1996; Dogancay-Aktuna, 2005; Guest, 2002; Moraine, 1976, Porto, 2010; Suzuki, 2010; Yuen, 2011). Rather than cultural orientation, Scarino (2010) highlights the intercultural orientation which aims at changes students' views throughout learning.

As an advantage of such a transition, Scarino states that "they come to understand culture not only as information about diverse people and their practices but also, and most importantly, as the contextual framework that people use to exchange meaning in communication with others and through which they understand their social world." $(2010$, p.324) Min (2007) categorizes culture in English under two phenomena; high culture, and anthropological culture. The first underlines the intellectual and artistic achievements; the second refers to any of the customs, worldviews, languages, and conventions that make some people distinct from other social group. Culture, accordingly, encompasses three aspects, that is, material culture, social (institutional) culture and ideological culture. 
Relation among cultures begins at the material level and gradually affects the social and ideological culture. As the material culture grows more, the social and ideological cultures change faster. In other words, micro level interaction leads to macro level influence.

However, this change is gradual and difficult, sometimes painstaking, even revolutionary. As a part of culture, ideologies find their clearest expressions in language. Language, as a special product of human society and an instrument of human thinking and communication, is a kind of institutional culture. Given the intermingled relationship between language and culture, the analysis of the ideological ground enriches the analysis of linguistic forms which show the language forms.

Behind linguistic utterances there lies an ideological background which influences the linguistic preferences and ways. This connection occurs at lexical-semantic and grammatical-semantic levels, and at the textual level (Hatim \& Mason, 1990; cited in Min, 2007, p.217). Peterson and Coltrane (2003, cited in Al-Issa, 2005 ) state that language and culture are interwoven and the students' success in achieving higher level of oral proficiency in target language relies on the consideration of culture in designing and developing course materials.

Cognitive and corpus linguistics have provided pedagogically sound approaches.

Given the language of thought as a continuum ranging from simple to complex units, including idioms, they play a significant role in the linguistic system but not merely for ornamental purposes in language. (Boers et al., 2008)

Research findings show that formulaic chunks constitute at least one-third to one-half of language (Erman and Warren 2000; Foster 2001; cited in Conklin\& Schmitt 2008; Howarth 1998; p.72). In the traditional view, idioms, „,notoriously difficult" (Celce-Murcia\& Larsen-Freeman, 1999) are considered special multiwords, and merely a matter of linguistic device with a special meaning and have certain syntactic properties. However, Kovecses (2002, p. 201) suggests that in contrast to traditional view, an idiom is not merely an extraordinary and somewhat complicated utterance of meaning which is special and hard to understand and requires deep linguistic knowledge, but many of them arises from our conceptual understanding comes from human's conceptual system which is natural and not subtle.

If figurative language such as idioms, metaphors, metonymies is pervasive in real life as a part of the culture, then it is not surprising that language learners will be certainly encountered and exposed with idiomatic expressions as a part of language learning and they should attempt to build up their knowledge of idioms if they want to survive in real communication settings. (Boers et al., 2004, p.376) However, idioms in particular are widely recognized to be a stumbling block (Buckingham, 2006) in the acquisition of a foreign language; though they are often recognized as incongruous, occasionally ungrammatical and difficult to figure out and resistant to translation for language learners and their contribution to communicative competence and intercultural awareness is both theoretically and empirically acknowledged (Boers et al, 2004; Kovecses\& Szabo, 1996; Lin, 2012; Littlemore\& Low 2006; Martinez \& Schmitt, 2012). English is a language which is full of idiomatic expressions, hence learning these idioms constitutes the spirit of language (Elkilic, 2008), and idioms have a considerable role in an L2.

Learning idiomatic expressions will enhance the students' communicative ability and will result in understanding cultural norms. (Samani and Hashemian, 2012, p. 249) As the meaning of idiomatic expressions are not formed within conventional rules and often seen non-compositional in nature (Fernando and Flavell, 1981), lack of reliable clues to understand and interpret has led to the assumption that the only way to learn idiomatic expressions is rote-learning (Boers et al., 2007). Cognitive semantic studies (Gibbs, 1994; Kövecses, 1990; Lakoff, 1987), however, there are many idioms which are not arbitrary but motivated by conceptual metaphoric and metonymic understanding. As in of the common examples, the conceptual metaphor TIME IS A MOVING OBJECT can be thought to motivate some figurative expressions that are frequently used in real life (e.g 'Time flies', 'I'm falling behind schedule again', and 'The holidays are approaching and those days are over') .To support this argument, Grant's finding (2004) attracts attention, thus Grant suggests that considerably small number of entries in idiom dictionaries is non-compositional and is therefore hard for learners. Another study (Boers, 2000) has shown that vocabulary retention can be facilitated by raising learners" metaphoric awareness".

Further, students have been found to recall idioms when they are connected with their literal meaning (Boers, 2001). Since the 1970s idioms have received significant attention and though in literature there have existed diverse idiom theories about idiomatic process (i.e. comprehension and production) (e.g. Cacciari \& Tabossi, 1988; Swinney and Cutler, 1979; Tabossi et al., 2009; Tabossi \& Zardon, 1993) it is strongly claimed native speakers of a language faster process idiomatic expressions compared to literal usage.

In addition to the studies with the native speakers, nonnative speakers have become the centre of studies in the literature with regard to idiom processing. For instance, Van Lancker-Sidtis (2003) investigated the impact of prosodic cues on helping the native and non native speakers in making a difference between two idiom interpretations. The results of study indicated that prosodic cues help native speakers to distinguish between figurative and literal use of idioms compared to the nonnative participants though they were proficient language users, and nonnative speakers had significantly more difficulties. Nevertheless,

Conklin and Schmitt (2008) did an experiment of self-paced moving- window reading to study how native and proficient non-native speakers comprehend idioms. The result of the study revealed that both groups read idioms faster than novel phrases and there is not any significant difference in both groups between figurative and literal meaning processing. 
Since the similar pattern was used in both groups, the researchers concluded that non-native speakers understand idioms in the same way as native speakers. Siyanova-Chanturia et al. (2011) investigated whether processing of figurative and literal interpretation of native and nonnative speakers differ in a story context.

They concluded that:

The findings suggested that non-native speakers more slowly processed the figurative expressions compared to the literal utterances and showed a similar performance to process idioms over novel phrases.

\section{DISCUSSION}

Vereshagn and Kastamarov (1990) have been recognized as language founders, in their book title "Language and culture," and argued that though people speak a common language, they may not properly understand each other due to intercultural differences. It is axiomatic that the language has a social nature and the main function of language is its instrumental role in communication between individuals. In addition, language is a tool for understanding the world, this means that language is not only a tool for informing but also it has the potential to provide information on the reflected person" s environment, and maintain records. Considering the relationship between culture and language in language learning, it can be said that culture has its own language - our culture by the architecture, painting, music, dance, and literature speaks. By using this tool, people can have ideas about how the environment under the impact of culture is expressed, interpreted, and spoken. Teaching experience in the past years shows that the university students after graduation, had gained a wide knowledge of linguistics, but while speaking (real communication) they are unable to communicate well. This is due to the factors beyond the language in the culture. Culture not only reflects the real world around humans and their living conditions, but a nation's social consciousness means thinking, lifestyle, traditions, value systems, and world views. Ter-Minasova (2000) states that language as a coating material for culture, in vocabulary, grammar rules, idioms, proverbs and interpretation, folklore, literature, science, in written and oral discourse, cultural values are maintained. Thus, it can be said that in any foreign language course such as clash of cultures and practical experience is cross-cultural communication because every foreign word reflects, the outside world and foreign cultures. Equivalent words do not create a problem for foreign person. They help to explain language by a simple method or translation. For example, the word book in Russian language книга , in Italian language libro, in Farsi Ketab, can be translated. Each of these words can share the same ideas connected with the word "book", would associate (books, novels, textbooks, bookstores, publishing book), and yet can make very different perceptions that data potentially exists in the human mind. Libro verde or green book, for Iranian is incomprehensible, in the minds of Italians refer on the collection of political documents that will be distributed at the Council House (Dehkhoda, 1994). In Turkey, for example When people add insult to injury, they make a bad situation even worse. "Tuz biber ekmek" (literally) to add salt and pepper means the same with the above expression. The phenomenon of salt attracts attention in that salt in Turkish life is widely used an d seen as the taste of life, and there are numerous figurative expressions in Turkish language using salt with both positive and negative meanings. To see the nexus between figurative language and culture, this example, to hear something straight from the horse's mouth (To hear something from the authoritative source) attracts attention. In Turkish, „Emir büyük yerden gelmek“ (The order coming from important or authoritative persons) the concept of authority, in other words government, has been always considered holy and respectful, one should obey the governments for stability, security, and good life, unlike modern view, person was for government and authority in Turkish history so everything is seen as an order from the authority. There is a well-known statement in Persian and Russian which says: a book is man's best friend Книга-друг лучший and Italian Un buon libro, è un buonamico A good book, is a good friend. If the word "booklet" and its Italian equivalent of the libretto, we see that the Italian word meaning only a small book, but the meaning of short written works "like a musical opera, ballet, plays and scenarios of a dictionary. The libretto refers to the booklet or office where the scores will be recorded in the schools of higher education. There is no such equivalent in Persian language, because there is no such booklet in the universities. But in the Persian language "booklet" is a term that means part of a detailed report, and the probe and twist of irony is the elaboration of the malevolence. (Najafi, 1990) The above examples can be concluded that the words can be conceptually equivalent completely, but in terms of schematic knowledge, they may not be entirely equivalent. Words with no equivalent throughout foreign language learning can cause many problems. Because it implies that the concepts in a language and culture may not exist in another. Thus, word and words with no equivalent of the former reflect the underlying characteristics of each nation's culture. Various thoughts on understanding various nations and nationalities come from different ways of thinking and cultural backgrounds. Therefore, their understanding of abstract equivalents and methods can vary as well. Finding two words in two distinct languages that have the same meanings are very rare. Some of the words often take advantage from specific cultural information, the words which have cultural charge such as the English word "dog"; a dog represents both a concept and an animal, but the differences are important. Europeans like dogs very much, therefore, in many cases, the use "dog" is conceived as a recognized and praised word. Given the importance of the word "dog", it represents the loyalty, intimacy and beloved.

\section{CONCLUSION}


Language and culture are closely connected to each other. Language embodies and transfers culture. Varieties in language use within culture create different views.

Learning a second culture is often intricately intertwined with learning a second language.

Teaching second language should be accompanied with teaching second culture.

The results of research findings will have implications for language teachers in general and policy makers in particular. Language teachers should equip themselves with the knowledge of second culture, make students familiar with cultural differences and have high esteem for students' native culture; thus facilitate the process of language learning. Language policy makers should consider different cultures equally well and develop positive attitudes towards target cultures especially in planning and designing materials, hence avoiding any culture shock and cultural misunderstandings.

Given a pedagogical perspective, knowing idioms not only makes the speech language learners productive and enriched, but also help them to learn and understand the thinking that the people learn the language. Interpretation in terms of culture means the study of language symbols and cultural concepts in foreign language classes, not only possible but also necessary. Idioms and the role of "language" in culture can integrate form and content, therefore, not only previous knowledge of the language teachers and their personal experience help, but numerous terminology of culture and interpretations are also important.

\section{REFERENCES}

[1] Agar, M. (1991). The biculture in bilingual. Language-in-Society, 20, 167-181.

[2] Al-Issa, A. (2005). The Role of English language culture in the Omani language education system: An Ideological Perspective. Language, Culture and Curriculum, 18 (3) 258-270.

[3] Alptekin, C. (2002). Towards intercultural communicative competence in ELT. ELT Journal 56(1), 57-64.

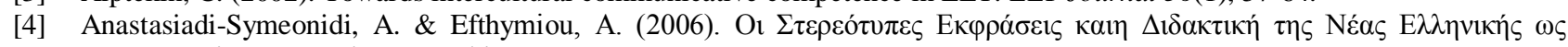

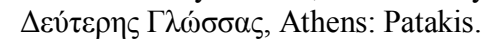

[5] Antipov, T. A., Donskikh O. A., Morkovina I. U., \&Sorokina U. A. (1368/1989). Text kak.

[6] Boers, F. (2001). Remembering figurative idioms by hypothesising about their origins. Prospect, 16, 35-43.

[7] Boers, F. Eyckmans, J., \& Stengers H. (2007).Presenting figurative idioms with a touch of etymology: More than mere mnemonics? Language Teaching Research 11(1), 43-62.

[8] Boers, F. (2000). Metaphor awareness and vocabulary retention. Applied Linguistics 21, 553-71.

[9] Boers, F., Lindstromberg S., Littlemore J., Stengers H.\& Eyckmans J. (2008). Variables in the mnemonic effectiveness of pictorial elucidation. In: Boers, F. \& S. Lindstromberg (eds.), 189-116. Berlin/New York: Mouton de Gruyter.

[10] Boers, F.,Eyckmans J., \& Demecheleer M. (2004). Cross-cultural variation as a variable in comprehending and remembering figurative idioms. European Journal of English Studies, 8(3), 375-388.

[11] Brown, H. (1994). Principles of language learning and teaching. 3rd edition. Englewood Cliffs, NJ: Prentice Hall Regents.

[12] Bygate, M. (2005). Applied linguistics: A pragmatic discipline, a generic discipline? Applied Linguistics. 26(4), 568-581.

[13] Cacciari, C., \&Tabossi P. (1988). The comprehension of idioms. Journal of Memory and Language, 27, 668-683.

[14] Celce-Murcia, M. \& Larsen-Freeman, D. (1999). The grammar book: An ESL/EFL teacher's course. 2nd edition. Boston, MA: Heinle \& Heinle.

[15] Charteris-Black, J. (2002). Second language figurative proficiency: A comparative study of Malay and English. Applied Linguistics, 23, 104-133.

[16] Conklin, K. \& Schmitt, N. (2008). Formulaic sequences: Are they processed more quickly than nonformulaic language by native and nonnative speakers?. Applied Linguistics, 29(1). 72-89.

[17] Cortazzi, M., \& Jin, L. (1996). Cultures of learning: Language classrooms in China, in H. Coleman (ed.) Society and the Language Classroom (pp. 169-206). Cambridge: Cambridge University Press.

[18] Dehkhoda, A. (1373/1994). Encyclopedic Dictionary. Tehran: Tehran University Publications. A small Dictionary of Proverbs.

[19] Deignan, A., Gabryś, D., \& Solska, A. (1997). Teaching English metaphors using cross-linguistic awareness-raising activities. ELT Journal, 51, 352-360.

[20] Elkilic, G. (2008). Turkish students' understanding of transparent and opaque idioms in English in reading as well as speaking. Journal of Language and Linguistic Studies, 4, 27-41.

[21] Ellis, N. C., Simpson-Vlach R., \& Maynard C. (2008). 'Formulaic language in native and second-language speakers psycholinguistics, corpus linguistics, and TESOL, TESOL Quarterly 41 375-96.

[22] Fernando, C. \& Flavell, R. (1981). On idiom: Critical views and perspectives. Exeter Linguistic Studies, 5. Exeter: University of Exeter.

[23] Gibbs, R. W. (1994). The poetics of mind: Figurative look on the bright side (consistent idiom) thought, language, and understanding. New York: Cambridge University Press.

[24] Glucksberg, S. (2001).Understanding Figurative Language. From Metaphors to Idioms, Oxford: OUP.

[25] Grant, L. (2004). A corpus-based investigation of idiomatic multiword units. PhD dissertation, Victoria University of Wellington.

[26] Guest, M. (2002). ‘A critical ‘checkbook’ for culture teaching and learning'. ELT Journal 56(2). 154-61.

[27] Jiang, W. (2000). The relationship between culture and language. ELT Journal 45 (4), 328-332.

[28] Kövecses, Z. (2002).Metaphor, Cambridge: Cambridge University Press.

[29] Kövecses, Z. (1990). Emotion Concepts. New York: Springer Verlag.

[30] Kövecses, Z. \& Szabo, P. (1996). Idioms: A view from cognitive linguistics. Applied Linguistics 17(3), 326-355.

[31] Lakoff, G. (1987). Women, Fire and Dangerous Things. What Categories Reveal about the Mind. Chicago: University of Chicago Press. 
[32] Lakoff, G. \& Johnson, M. (1980). Metaphors We Live By, Chicago: University of Chicago Press.

[33] Liddicoat, A. J. (2005). 'Teaching languages for intercultural communication' in D. Cunningham and A. Hatoss (eds.). An International Perspective on Language Policies, Practices and Proficiencies. Belgrave, Australia: FIPLV.

[34] Lin, P.M.S. (2012). Sound evidence: The missing piece of the jigsaw in formulaic language research. Applied Linguistics, 33(3), 342-347.

[35] Littlemore, J., \& Low, G. (2006). Metaphoric competence, second language learning, and communicative language ability. Applied Linguistics, 27(2)268-294.

[36] Liu, D. (2002) .Metaphor, Culture, and Worldview: The Case of American English and the Chinese Language, Lanham, MD: University Press of America.

[37] MacKenzie, I. (2012). English as a lingua franca in Europe: Bilingualism and multicompetence. International Journal of Multilingualism, 9(1), 83-100.

[38] Martinez, R., \&Schmitt, N. (2012). A Phrasal Expressions List. Applied Linguistics, 33(3), 299-320.

[39] Min, F. (2007). Cultural issues in Chinese idioms translation. Perspectives: Studies in Translatology, 15(4), $215-229$.

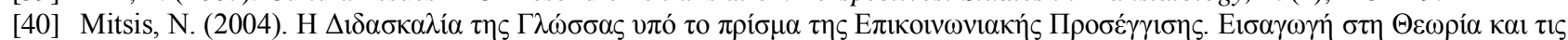

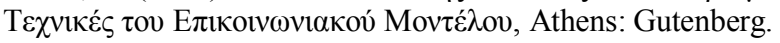

[41] Morain, G. (1976). 'Visual literacy: Reading signs and designs in the foreign culture'. Foreign Language Annals, 9(3), $210-16$.

[42] Najafi, Abolhassan. (1378/1999). Farhange Farsi e Amianeh. Tehran: Entesharate Niloufar.

[43] Peterson, E.and Coltrane, B. (2003.) Culture in second language teaching. Retreived on 01.07.2012 from http://www.cal.org/resources/digest/peyton02.html.

[44] Porto, M. (2010). Culturally responsive L2 education: An awareness-raising proposal. ELT Journal, 64(1), 45-53.

[45] Risager, K. (2007). Language and Culture Pedagogy. From a National to a Transnational Paradigm. Clevedon: Multilingual Matters Ltd.

[46] Samani, E. R., \& Hashemian M. (2012). The effect of conceptual metaphors on learning idioms by 12 learners. International Journal of English Linguistics, 2 (1) 249-256.

[47] Dogancay-Aktuna, S. (2005). Intercultural communication in English language teacher education. ELT Journal, 59(2), 99-107.

[48] Scarino, A. (2010). Assessing intercultural capability in learning languages: A renewed understanding of language, culture, learning, and the nature of assessment. Modern Language Journal, 94(2), 324- 329.

[49] Sinclair, J. (1991). Corpus, concordance, collocation. Oxford: Oxford University Press.

[50] Siyanova, A., K. Conklin, \& Schmitt, N. (2011). 'Adding more fuel to the fire: An eye-tracking study of idiom processing by native and non-native speakers. Second Language Research, 27(2) 251-72.

[51] Suzuki, A. (2010). Introducing diversity of English into ELT: Student teachers' responses'. ELT Journal, 65(2), 145-53.

[52] Swinney, D., \& Cutler, A. (1979) .The access and processing of idiomatic expressions. Journal of Verbal Learning and Verbal Behavior, 18, 523-534.

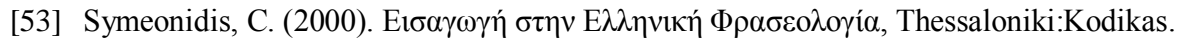

[54] Tabossi, P, Fanari R, \& Wolf K. (2009). Why are idioms recognized fast? Memory and Cognition, 37, 529-40.

[55] Telia, V. N. (1385/2006). Bolshoi fraziologicheski Slovar ruskova yazika, Znachenie,Upotriblenie, Kulturologicheski komentari (Большой фразеологический словарьрусского языка, Значение. Употребление. Культурологический комментарий).

[56] Vanlancker-Sidtis, D. (2003). Auditory recognition of idioms by native and nonnative speakers of English: It takes one to know one, Applied Psycholinguistics, 24, 45-57.

[57] Conklin K \& Schmitt N. (2008). Formulaic sequences: Are they processed more quickly than nonformulaic language by native and non-native speakers? Applied Linguistics, 29, 72-89.

[58] Chen, Y., \& Lai, H. (2011). Proceedings from 25th Pacific Asia Conference on Language, Information and Computation.

[59] Vereshagin, E. M, Kastamarov V. G. (1369/1990). Yazik i kultura (Язык и культура),Moscow. Russki Yazik.

[60] Winney, D. \& Cutler, A. (1979) .The access and processing of idiomatic expressions. Journal of Verbal Learning and Verbal Behaviour, 18, 523-34.

[61] Wray, A. (2002). Formulaic Language and the Lexicon. Cambridge: Cambridge University Press.

[62] Telia, V. N. (1385/2006). Bolshoi fraziologicheski Slovar ruskova yazika, Znachenie, Upotriblenie, Kulturologicheski komentari (Большой фразеологический словарь русского языка, Значение. Употребление. Культурологический комментарий). Moscow: Ast-Press Publications.

[63] Ter-Minasova, S. T. (1379/2000). Yaziki i mejkulturnaya komunikatcia (Языки имежкультурная коммуникация). Моscow. Slova.

[64] Yuen, K. (2011). The representation of foreign cultures in English textbooks. ELT Journal, 65(4), 458-466.

Oktay Yağız is an assistant professor at Atatürk University, Turkey. He is the vice director of the School of Foreign Languages at Atatürk University as well. His research fields are EFL teaching and learning, academic writing, applied linguistics and English for Academic Purposes. He focuses on tertiary level education. He has been working on national and international research projects.

Siros Izadpanah is currently a Ph.D student in TEFL at Atatürk University .He is now a faculty member at Islamic Azad University ,Zanjan Branch,Iran . He has presented and published a number of articles in international conferences and journals ,and also published a few books in the field of TEFL. 